\title{
Strikes and the law; the problems of legal intervention in labour disputes
}

\author{
Gordon Anderson*
}

This paper sets out some of the background to the provisions in the Labour Relations Act 1987 that regulate the right of trade unions to strike and that set out the legal consequences that apply if a strike is contrary to the provisions of the Act. These issues are discussed with an emphasis on some of the difficulties that existed before 1987. The paper will conclude with a discussion of the policy options available to the Goverment at that time and of the various submissions and proposals made by the major parties. The provisions in the Labour Relations Act and their application in practice are dealt with in a second paper in this symposium (Hughes and Anderson, 1988).

\section{Introduction}

Legal intervention in industrial relations has always been a topic that creates considerable controversy both as to the extent that such intervention should occur and as to its desirability. In understanding the problems that exist and the solutions to them that were attempted in the Labour Relations Act it is important to have some understanding of the background to the development of the law. In particular, the fact that the law has generally been hostile to trade unionism and to collective action must be recognised and taken into account. It is well known that one of the most significant barriers to the growth of effective trade unionism throughout the nineteenth century was judicial hostility to the trade union movement and to collective action by workers. This early history has conditioned much of the present hostility and suspicion directed towards the law and to the courts from amongst trade unionists. Moreover twentieth century developments have not helped to remove these suspicions. In New Zealand one only has to consider the advent of the labour injunction or of the extremely restrictive view of the ultra vires doctrine that the courts applied to the objects of trade unions. In the United Kingdom, still a major source of New Zealand law, the courts have steadily increased the scope of the economic torts and have taken a restrictive view of legislation designed to protect union rights (Wedderburn, 1986, ch. 7-8).

The present law is to a large extent a reflection of the neccesity to overcome the hostility of the law and of the judiciary so as to create a legal environment in which trade unions are able to operate with some degree of effectiveness. It is these efforts, for example, that have given rise to the debate over so-called trade union "immunities" and to the subsequent argument that trade unions are in some way above the law. Because of these efforts 
collective labour law has developed largely as a collection of exceptions to the common law.

A second point that warrants some consideration is the question of the ideological premises that underly the present law and the attitudes of the judiciary towards unionism and to collective action. Modern labour law is a mixture of statute and common law and naturally reflects the premises that exist in these areas of law. This is particulary apparent in the case of the common law which is dominated by the notions of freedom of contract and assumed equality of bargaining power as well as a particular perspective of property rights. Many modern labour law academics have argued for the autonomy of labour law, that is the concept that labour law should be treated as a separate branch of the law embodying its own values that are appropriate to industrial relations, an approach which it is hoped will help overcome some of the problems in the present legal structure. This approach involves a radical re-thinking of the values appropriate to labour law and a major departure from those values that presently prevail such as the subordinate position of the worker and the assumed property rights of the employer (see the arguments summarised in Wedderburn, 1987 pp.1-4).

\section{The possibilities for legal intervention}

The law can intervene in an industrial dispute in a number of ways although these may not neccesarily be consistent and may overlap or, indeed, be in conflict with each other. The main possibilities for intervention, put perhaps simplistically, are:

(1) The criminal law: This was the basis of the first of the nineteenth century legal attacks on unions when unions were regarded as illegal and as criminal conspiracies. Wedderburn (1986, p. 578) refers to one case, $R$ v Selsby where strikers were faced with an indictment of 4914 counts and 57 yards long. Direct intervention by the criminal law is now of no significance in New Zealand, although it should be remembered that strikers were liable to criminal penalties until 1978 under the Industrial Relations Act and even later under under Part IVA of the Commerce Act 1975. The criminal law today is however still relevant to the conduct of a strike and in particular to the conduct of picketing. It is deceptively easy to be guilty of such offences as trespass, obstruction, offensive language or assault.

(2) Civil liability in common law for the consequences of industrial action: The most well known form of this intervention is of course through the various economic torts, although there are other possibilities available including breach of contract and the recent innovation of economic duress.

(3) Statutory intervention: Unlike the first two cases, which are primarily cases of judicial intervention, statutory intervention is predominately political in nature and normally intended to have a general reforming effect on the law. Statutory intervention can take many forms, from ad hoc legislation to deal with a particular issue, ${ }^{1}$ to a comprehensive code of labour law. Statutory intervention does not of course preclude judicial intervention. Indeed the judiciary are often central to the implementation of legislation, an influence that can be crucial to its success as the judicial interpretation of legislation can have a significant effect on the operation of the law in practice and in some cases can alter the legislative intentions. 
(4) Finally there is what could be termed "total intervention", which is a combination of all the above forms of intervention in combination with the deployment of the state's coercive resources, normally in the form of the police and the military. This type of intervention is unusual, at least in recent times, and is normally reserved for what a government regards as a major threat to law and order or to its economic or social policies. The two main examples in New Zealand are the 1912-13 Waihi and General strikes and the 1951 waterfront dispute. A more recent example is the British miners' strike in 1984-85.

In practice of course industrial relations and industrial disputes are subjected to a combination of all the above forms of intervention.

\section{Legal intervention in New Zealand}

Before looking at some particular problems that result from the intervention of the law into industrial disputes it is worth recalling something of the history and of the changes in philosophy that have occurred in New Zealand's industrial law since 1894, and more particularly since the 1970 s.

One of the major aims of the Industrial Conciliation and Arbitration Act of 1894 was to end the need for strikes and to substitute a system of judicial arbitration through the Court of Arbitration (Holt, 1986, ch. 1). In order to facilitate this, strikes were proscribed in most circumstances and criminal sanctions made available against striking workers. In practice however, strikes gradually became acceptable, or probably more accurately, tolerated within limits. Attempts to prosecute strikers were also soon found to resolve neither the strike nor indeed to be a particularly satisfactory form of legal proceeding. A real gap between the legislative structure and industrial relations practice became more apparent in the post-war years and particularly in the 1960s and 1970s as New Zealand moved towards what was, in effect, a collective bargaining system where strikes were becoming an increasingly common aspect of bargaining behavior. These changes were acknowledged in the Industrial Conciliation and Arbitration Amendment Act 1970 when new dispute procedures were introduced and a clear distinction between interest and rights disputes began to emerge.

The Industrial Relations Act 1973 completed this process and for the first time some attempt was made to define the circumstances in which strikes should not attract legal sanctions. The Act removed statutory penalties for strikes during a dispute of interest subject to the dispute not being before a conciliation council. At the same time a variety of new disputes procedures were reformed or introduced to deal with disputes of rights including personal grievances. ${ }^{2}$ The basic scheme that was eventually to reach fruition in the 1987 Act had thus begun to emerge, that is that strikes were permissible in resolving disputes of interest but that disputes of right should be settled by set procedures and if neccesary by resort to the Arbitration Court.

A second issue raised in 1973, that of the appropriate sanctions for striking in breach of the Act and in particular whether such actions should be regarded as criminal, was not 
however resolved until 1978 when the recommendations in the Dunlop Report (1978) ${ }^{3}$ were enacted by the then National Government. This Report concluded that criminal penalties for striking were inappropriate and should be replaced with civil penalties. The major reasons for this conclusion seem to have been that criminal sanctions introduced inflexibility into the administration of the legislation and limited the extent to which industrial relations factors could be taken into account by the Department of Labour when considering a decision to prosecute. Prosecutions were also seen as causing considerable practical difficulties especially when large numbers of prosecutions were being considered as had been the case during the events leading up to the report. These problems, could it was felt, be overcome by introducing civil sanctions. Since 1978 such penalties have been used by employers rather than the government. ${ }^{4}$

In 1973 a new code to govern New Zealand's industrial relations system was implemented, a code that was designed to cope with some of the major changes that had occurred in the industrial relations system over the last two decades. At the same time however, these developments were put at risk and the logic of the Act's structure was threatened by the intrusion of the common law into the industrial relations arena.

\section{The intrusion of the common law}

Two decisions of the Supreme Court in 1970; Pete's Towing Services v Northern IUW and Flett $v$ Northern Transport Drivers IUW introduced a new dimension to the application of the common law to the conduct of industrial disputesin New Zealand. The Court of Appeal's 1973 decision in Northern Drivers IUW v Kawau Island Ferries Ltd affirmed and consolidated this development. This intrusion and the reasons why it should have been resisted have been discussed elsewhere (Anderson, 1987) but the main points should be reiterated.

The most important is that this development was in effect, if not in terms of conventional legal theory, an intrusion of foreign law into the existing statutory system of New Zealand labour law. United Kingdom law, or to be precise the common law component of English law, was taken from its own peculiar environment and transplanted in New Zealand. The part not transplanted moreover was that part of the law that had been carefully structured in the United Kingdom to limit the excesses that the development of the common law had led to. This transplant took place without debate or consultation and was carried out by a few judges whose understanding of industrial relations realities was probably limited.

To fully appreciate the significance of this argument, it must be remembered that since 1906 trade unions in the United Kingdom have had the benefit of statutory immunity from most actions in tort that arise in the course of an industrial dispute. The judiciary have thus been free to develop the common law in a way that would almost certainly have been inconceivable in the absence of those immunities. The economic torts as developed in the United Kingdom barely acknowledge that unions and collective action have any legitimate function whatsoever. Clark and Wedderburn $(1983$, p. 141) put the matter thus: "in the face of common law liabilities trade unions have no rights to function or even to exist." In the absence of these immunities the common law would probably have remained

The original Act passed by a Labour Govemment removed penalties but they were reinserted by a later National Government. See for example Osbourne v Robertson . 
extremely restrictive but it is extremely unlikely that the judiciary could have travelled through the greatest part of this century without developing the common law to take some account of trade union activities. Instead the immunities allowed the issue of union legitimacy to be avoided and if anything probably worsened the position at common law. The judiciary has seldom concealed its distaste of the immunities (Clark and Wedderburn, 1983, pp. 166-173). It was this extremely skewed version of the common law that was transplanted into New Zealand. The significance of the intrusion by the common law and its potential impact can be judged by looking at the range of consequences that resulted:

(1) The legislative policy of the previous 80 years, that industrial disputes should be litigated in a specialist court, was negated. Moreover the state of the common law was such that employers gained significant tactical and legal advantages by resorting to the courts of general jurisdiction rather than the Arbitration Court.

(2) The possibility of a conflict between the statute and the common law arose. For example, a strike permitted by statute could well be unlawful at common law. In addition, the system of statutory dispute settlement procedures was undermined by allowing access to an altemative system where the industrial issues were largely irrelevant.

(3) The potential for a major legal attack on the trade union movement as a whole arose. The common law permitted potential actions to recover damages to such an extent that the trade union movement's viability could have been threatened, either directly through the financial costs such actions would have imposed or because of the chilling effect they could have had on the willingness of a union to become involved in strikes. In practice this did not occur, although there has been an increasing use of the common law to prevent or to stop strikes by the use of injunctions and in the last few years some indications that damages may be sought against unions on a substantial scale (Hughes, 1987).

(4) The labour injunction became available as a weapon in industrial disputes. The injunction was a weapon that particularly favoured employers and as such resulted in a major change in the balance of power in industrial disputes.

\section{The labour injunction}

Probably the most controversial judicial intervention into labour disputes has been through the use of the injunction, and in particular the interlocutory injunction, as a means of restraining or preventing strikes or other forms of industrial action by workers and their unions. The labour injunction has, probably accurately, been described by one American unionist as "the most perfect ... strike-breaking agency there is on earth" (Mills and Montgomery, 1945 p. 631), a description that accounts for the hostility of trade unions towards its use. It has also been said that it is "society's way of emulating the ostrich by sticking its head in the sand" (Cox, 1967 p. 693). This latter description, while directed to the fact that such injunctions do not solve the underlying problems that result in strikes, could equally accurately describe the response of the legal system, and that of much of the judiciary, to the realities of industrial life and to collective action by workers.

Although the injunction as a strike breaking weapon gained its greatest notoriety in the United States after Re Deb's in 1895, injunctions had been issued in cases involving 


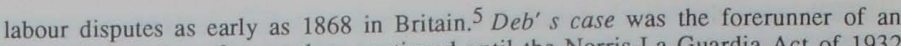
increasing number of cases that continued until the Norris-La Guardia Act of 1932 restricted their application in that country. In the United Kingdom, labour injunctions have been commonly used since the war and increasingly since the Conservative Government's restrictions on union immunities and on the right to strike that were enacted after the 1979 election. In New Zealand the injunction seems to have first appeared in 1970 and since that time it has been reasonably popular with employers and increasingly so in recent years.

The arguments against labour injunctions are well known, and have been refered to in a previous paper (Boast, 1988), and the details of their application in New Zealand labour law have been well described by Hughes (1986). It is nevertheless worth reviewing some points in a little detail. The list of arguments below are partially derived from an article published in 1937 and written by a lawyer who went on to become Chief Justice of Canada (Laskin, 1937), showing perhaps how little attitudes and the law have changed in the intervening fifty years. The major arguments against labour injunctions are:

(1) In the majority of cases they act as a final determination of the issues involved. Once the immediate aim of breaking the strike has been achieved and a return to work forced, the employer will not not normally be interested in pursuing the matter to a full hearing. Even if this was done and the union's case upheld, the issue in dispute would be long dead and have been decided in circumstances where the union's bargaining position was considerably weakened. It is this reason in particular that leads on to many of the points made below. An interim injunction may well be appropriate where the preservation of the status quo involves a static position being preserved but this is far less obvious in a dynamic situation that typifies an industrial dispute.

(2) The procedure gives a considerable tactical advantage to the employer. The employer as plaintiff can choose when to initiate an action and will inevitably do so at a time to gain the maximum advantage. A cynic could well think that many ex parte applications are sought not for reasons of genuine urgency but for the tactical advantage given. When advance notice of the strike is given, or the strike is otherwise predictable, the employer's solicitors can prepare the case with care and with a degree of leisure, and the same time, by late filing put considerable pressure on the solicitors for the union. Thus even before the union and its solicitors reach the court doors they may already be at a considerable disadvantage.

(3) Interlocutory injunctions are granted on affidavit evidence. The problems with such evidence is that it is not subject to cross-examination, and as Laskin puts it, "the judge . .. is asked to choose between conflicting documentary statements in which both sides strain the truth to say the least" $(1937$, p. 271). This latter problem is of course avoided altogether where an ex parte injunction is sought. In an interlocutory hearing the employer may also have a considerable advantage in the presentation of evidence as it is the employer who initiates the proceedings and is thus in a position to ensure that their evidence is better prepared. Careful timing is also more likely to see the union unprepared to counter such evidence. Faced with carefully prepared evidence, especially if one side is not represented a judge may have little choice but to take that evidence at face value. As it is unlikely that an action will ever reach a full trial the result is that the case is determined on, at best, unsatisfactory evidence.

Springhead Spinning Co v Riley and see generally Thomson (1966). 
(4) The tests used by the courts favour the employer. The American Cyanimid "serious issue to be tried" test means that the threshold the employers case must meet falls well below that which will be needed at the full hearing. If the union does raise possible defences or questions of factual dispute they are likely to be seen as being issues best left for a full hearing.

The second test, that of "the balance of convenience" will also generally favour the employer. It is not difficult, especially given time to prepare, to present evidence to show considerable losses involved should the strike be allowed to continue. Union arguments directed to more intangible losses such as loss of bargaining position, even if accepted, are unlikely to be convincing. The courts prefer to think in financial terms. Employers suffer financial losses compared to the intangible and non-quantifiable loss that a union could claim. Moreover any financial loss the union or its members suffer is likely to be small and easily meet by an employer. The opposite applies to the union. The limited financial resources of the union to meet a possible award of damages are seen as an additional argument favouring the grant of an injunction.

(5) Finally there is the argument that the labour injunction is perceived by workers and unions as putting the courts, as Laskin puts it, "in the ranks of the employer". This perception can only undermine the respect for the court involved and lessen confidence in the law generally.

In a discussion of labour injunctions it is important to appreciate that two issues are involved. The first is the underlying law which provides the base on which the application for an injunction is founded. Equally important however is the procedural and evidential basis on which the application is decided.

\section{The underlying law}

The present paper is not the place for a detailed discussion of the law that is applicable to industrial conflict. The law is both complex and uncertain in its detail. Nevertheless some understanding of the essential nature of this law is necessary to appreciate both the problems that arise with applications for labour injunctions and with common law actions in general in industrial relations cases. In order to bring an application for an injunction, or any other remedy, a plaintiff must show that a legal right that has, in some way, been violated. In an industrial dispute this is normally achieved by showing that a union or its officials or its members are committing one or more of the economic torts in carrying out their industrial action. These torts are such that it is almost inevitable that a strike will result in at at least one of them being committed. Much of this branch of the law has in fact been been developed in cases concerning strikes and by a judiciary whose sympathies were seldom with the strikers. The tort of inducement to breach of contract is perhaps a good example. Any strike is almost certain to involve union officials and the union inducing workers to breach their contracts of employment and thus rendering the union and its officials liable in tort. While there is a defence of justification available the courts have never recognised trade union objectives as coming within this defence. This tort has, since the 1950 s, steadily been broadened almost always to the detriment of unions (Wedderburn, $1986 \mathrm{ch} .8)$.

In the context of an interlocutory injunction the details of the actual law may however be of little importance because what matters is whether there is a serious issue to be tried. A good lawyer, given the state of the law, should have little trouble establishing that there is a convincing argument that in fact this is the case. The argument as to whether in fact 
there has been a tort committed and whether there is a good defence is left to the full hearing should it ever take place.

\section{Procedure in injunction applications}

In an injunction application the procedural aspects as they relate to the form of evidence and the tests to be applied by the courts in deciding the application are of perhaps greater importance than the legal basis of the application. These tests have beeen discussed by Boast (1988, p. 33-34). At this point little needs to be added except the point that both the procedures and the tests used are far from satisfactory in cases involving industrial conflict.

\section{Trade union "immunities"}

If it is accepted that the common law makes the operation of trade unions and the viability of collective action untenable then the question of what protection should be given to trade union action must be addressed. One would hope that in New Zealand it is now generally, if not universally, accepted that workers have the right to organise through trade unions and to take collective action in respect of their conditions of employment. The limits to this right are obviously, subject to some debate. In common law countries this debate has been clouded by the form in which these rights have been granted. Unlike the situation in many countries where unions have been granted positive rights in relation to their collective bargaining activities, common law countries have granted "immunities" from some of the legal liabilities that would otherwise apply to trade unions. It is this technique that is largely responsible for claims that unions are in some way above the law. In spite of occasional views to the contrary, usually from the economic right, (e.g.Tur, 1982) these arguments have been shown on many occasions to be false (e.g. Clark \& Wedderburn, 1983, Kahn-Freund, 1977) and it has been accepted by the Conservative Government in the United Kingdom that some degree of legal protection is neccessary if unions are to operate effectively (Department of Employment, 1981).

The question of trade union immunities from common law liability does not, prior to 1985 , seem to have been seriously discussed in New Zealand.

\section{The Green Paper debate and policy options}

When the Government announced its intention to undertake a review of New Zealand's industrial law the possibility for a major review of the basis of the right to strike and of the structure and suitability of the statutory-common law mix seemed likely. Such a review to be effective needed a fundamental reappraisal of both law and practice and a consequent reconstruction of a New Zealand law of industrial conflict. Unfortunately, and for whatever reasons, this was not done by either the Government or by the major parties to the debate. Instead a pre-occupation with existing law, and in particular the common law, led to an unwillingness to undertake the fundamental remodelling that was required to give a coherent legal structure.

\section{The problems}

The discussion above has highlighted the main problems that existed in 1986. In summary they were: 
(1) New Zealand's law governing industrial conflict had become an unfortunate mixture of common law and statute with the two often conflicting and with the legislative policy being at variance with the common law in some situations. The fact that much of this law was created in a foreign country and was transplanted to New Zealand with little or no consideration as to its suitability hardly improved matters.

(2) The fundamental issue of whether and to what extent trade unions should have a right to strike had never been adequately addressed in legal terms. Moreover social, political and industrial relations beliefs and practice did not accord with those of the law.

(3) The combination of common law and statute had resulted in New Zealand having one of the most restrictive systems of strike law amongst democratic countries.

\section{The responses}

In the Green Paper (1985, p. 276) the Government stated that it was seeking to provide legislation that "is relevant and respected." The accompanying discussion however, while describing the law existing at the time in some detail, did not directly confront the issues that needed to be dealt with. Thus the word "immunities" is not used in the very brief and vague discussion on whether the common law should be "restricted". The more fundamental question of whether United Kingdom law is appropriate in New Zealand was not even raised. Indeed the myth of a universal common law is probably such that the question may not even have occurred to the authors of the Green Paper.

The major submissions also failed to come to grips with the problem of creating a specifically New Zealand law of industrial conflict. The Employers' Federation submission (1986) merely stated that "common law action should contiue to be available" and that "there is no reason why either unions or employers should not remain accountable for unlawful actions under common law procedures." While this, for the Employers' Federation, is an understandable position, it could perhaps have been expected that some of the substantial issues that this brief part of the submission glossed over might have been addressed. The Federation of Labour's submission (1986) is a little more detailed on this point and the need for some review of the law was recognised. Indeed the need to recognise union rights in a positive way was expressly mentioned. Unfortunately the Federation seemed to fall back on the United Kingdom "immunity" solution rather than going foward to suggest some new proposal designed for New Zealand conditions. The summary of submissions (Department of Labour, 1986) also seemed to show that the overall pattern of submissions was varied and generally in conflict. This is of course not surprising given the range of views on strikes and the emotions that both strikes and unions generate. This range of submissions does not however aid sensible decision making and the resulting Act is something of a compromise rather than a rational solution.

\section{The solutions}

The details of the 1987 reforms are discussed in detail in a later paper in this symposium (Hughes and Anderson, 1988). At this stage they are merely outlined.

(1) The common law was left untouched in relation to both injunctions and actions for damages. The problem of conflicting policies was overcome by the grant of a limited immunity to trade unions in respect of strikes specifically defined as "lawful".

(2) A very limited "right" to strike was created. 
(3) The transfer of the majority of potential litigation resulting from strikes to the Labour Court was adopted as a means of overcoming the problems of having two different courts involved in such litigation.

\section{Conclusion}

At the time the Labour Relations Act 1987 was passed the New Zealand law governing industrial conflict was suffering from serious conceptual problems that were fundamental to the whole structure of the law. Rather than address these problems the choice was made to opt for pragmatic compromise and to try and patch up an inadequate system. None of the problems inherent in the common law have been addressed and equally the state of the law on labour injunctions remains virtually unchanged. Indeed decades of considered criticism of this device seem to have had little impact on either the courts or the legislature. Whether the changes made will be effective remains to be seen. What is tragic is that the probably the one major chance for the immediate future to consider the issues raised and to create a genuine New Zealand system of industrial law has been lost.

In the opinion of the writer, these problems could best have been solved by the creation of a genuine code governing collective labour law in New Zealand. Industrial law is a field that is, more than any other, linked to the local political, social and economic environment. For that reason, the law should be the product of that environment. New Zealand has adopted this solution in many other areas where the common law has proved defective or out of touch with local conditions. One of the earliest examples was the criminal law and more recently significant areas of contract law have been codified. One would have thought that industrial law could have been similiarly treated. This process need not prejudge the terms of the debate, for a code can be just as restrictive as the common law. What codification might have achieved is a more rational and New Zealandbased law.

\section{References}

Anderson, G (1987) The reception of the economic torts into New Zealand labour law: a preliminary discussion New Zealand journal of industrial relations 12(2): 89-100.

Boast, R (1988) Injunctions and compliance orders: some procedural issues New Zealand journal of industrial relations 13(1): $33-40$

Clark, J and Wedderburn, Lord (1983) Modern labour law: problems, functions and policies. In Wedderburn, Lord et al. (Ed) Labour law and industrial relations: building on Kahn-Freund Oxford, Clarendon Press.

Cox, A (1967) The role of the law in labor disputes. In Bakke et al. (Ed) Unions, management and the public New York.

Department of Employment (1981) Green Paper on trade union immunities London, HMSO.

Department of Labour (1986) Industrial relations: a framework for review : summary of submissions Wellington, Government Printer. 
Dunlop Report (1978) Report on the application of the penalty provisions of the Industrial Relations Act: report by Sir William Dunlop.

Employers Federation (1986) The industrial relations Green Paper: an employer perspective Wellington, NZEF.

Federation of Labour (1986) Looking ahead: a more just industrial relations system, Wellington, NZFOL.

Green Paper (1986) Industrial relations: a framework for review Wellington, Government Printer.

Holt, J (1986) Compulsory arbitration in New Zealand: the first forty years Auckland, Auckland University Press.

Hughes, J (1986) Injunctions against strikers Otago law review 6: 306-318.

Hughes, J (1987) Damages in the economic torts New Zealand journal of industrial relations 12(2): 101-105.

Hughes, J and Anderson, G (1988) The Labour Relations Act in practice: an analysis of the Labour Court's powers and decisions New Zealand journal of industrial relations 13(1): 49-62.

Laskin, B (1937) The labour injunction in Canada: a caveat The Canadian bar review 15: 270-284.

Mills, H and Montgomery, R (1945) Organized labour New York, McGraw Hill.

Thomson, A (1966) The injunction in trade disputes in Britain before 1910 Industrial and labour relations review 19: 213-223.

Tur, R (1982) The legitimacy of industrial action: trade unionism at the crossroads. In Wedderburn, Lord and Murphy, W (Eds) Labour law and the community London, Institute of Advanced Legal Studies.

Wedderburn, Lord (1986) The worker and the law Harmondsworth, Penguin.

Wedderburn, Lord (1987) Labour law: from here to autonomy? The industrial law journal 16: 1-29.

\section{List of cases}

American Cyanimid v Ethicon [1975] 1 All ER 504 (HL).

Flett v Northern Transport Drivers IUW [1970] NZLR 1050.

Osbourne v Robertson [1985] 2 NZLR 680.

Northern Drivers IUW v Kawau Island Ferries Ltd [1974] NZLR 617 (CA).

Petes Towing Services v Northern IUW [1970] NZLR 32.' 
32 Gordon Anderson

$R$ v Selsby (1847) 5 Cox 495n.

Re Deb's 158 US 164 (1895).

Springhead Spinning Co v Riley (1866) LR 6 Eq. 555. 